\title{
Serum NT-proBNP Levels Are Not Related to Vitamin D Status in Young Patients with Congenital Heart Defects
}

\author{
E. Passeri, ${ }^{1}$ R. Rigolini, ${ }^{2}$ E. Costa, ${ }^{2}$ C. Verdelli, ${ }^{3}$ C. Arcidiacono, \\ M. Carminati, ${ }^{4}$ and S. Corbetta ${ }^{5}$ \\ ${ }^{1}$ Endocrinology Unit, IRCCS Policlinico San Donato, 20097 San Donato Milanese, Italy \\ ${ }^{2}$ Laboratorio di Chimica Clinica, IRCCS Policlinico San Donato, 20097 San Donato Milanese, Italy \\ ${ }^{3}$ Laboratory of Molecular Biology, IRCCS Policlinico San Donato, 20097 San Donato Milanese, Italy \\ ${ }^{4}$ Pediatric Cardiosurgery, IRCCS Policlinico San Donato, 20097 San Donato Milanese, Italy \\ ${ }^{5}$ Endocrinology Unit, Department of Biomedical Sciences for Health, University of Milan, \\ IRCCS Policlinico San Donato, 20097 San Donato Milanese, Italy \\ Correspondence should be addressed to S. Corbetta; sabrina.corbetta@unimi.it
}

Received 30 August 2015; Revised 1 November 2015; Accepted 4 November 2015

Academic Editor: Yi-Chia Huang

Copyright (C) 2016 E. Passeri et al. This is an open access article distributed under the Creative Commons Attribution License, which permits unrestricted use, distribution, and reproduction in any medium, provided the original work is properly cited.

\begin{abstract}
Context. Hypovitaminosis D frequently occurs in early life and increases with age. Vitamin D has been suggested to influence cardiac performance and N-terminal-pro-type B natriuretic peptide (NT-proBNP) release in adults with heart failure. Objectives. To assess the vitamin D status and the impact of hypovitaminosis D on circulating NT-proBNP levels in young patients with congenital heart defects (CHD). Design and Patients. This cross-sectional study included the assessment of serum 25-hydroxyvitamin D (25OHD), parathyroid function markers, and NT-proBNP levels in a series of 230 young in-patients (117 females, 113 males; 6.4 (4.0-9.1) years (median, interquartile range)) with CHD. Results. Serum $25 \mathrm{OHD}$ levels $<20 \mathrm{ng} / \mathrm{mL}$ were detected in $55.3 \%$ of patients. Optimal $25 \mathrm{OHD}$ levels $(>30 \mathrm{ng} / \mathrm{mL})$ occurred in $25 \%$ of patients. Serum $25 \mathrm{OHD}$ levels inversely correlated with age $(r=-0.169, P=0.013)$ and height standard deviation score $(r=-0.269, P=0.001)$. After correction for age, 25OHD negatively correlated with serum PTH levels $(\beta=-0.200, P=0.002)$. PTH levels above the upper quartile ( $44 \mathrm{pg} / \mathrm{mL}$ ) occurred in $32 \%$ of hypovitaminosis D patients. Serum NT-proBNP levels were not correlated with 25OHD and PTH levels. Conclusions. Half of the young CHD patients were diagnosed with 25OHD deficiency and a third of hypovitaminosis D patients experienced hyperparathyroidism. Nonetheless, serum NT-proBNP levels were not associated with hypovitaminosis D as well as hyperparathyroidism.
\end{abstract}

\section{Introduction}

Congenital heart defects (CHD) occur in $0.5-0.9 \%$ of newborns and survival is substantially improved in the last decades [1-5]. From a pathophysiologic standpoint, CHD may be characterized by (1) increased volume overload (i.e., defects characterized by left-to-right shunt, such as ventricular septal defect, patent ductus arteriosus, truncus arteriosus, atrial septal defect, and atrioventricular septal defects); (2) pressure overload involving the left ventricle (i.e., aortic stenosis and aortic coarctation) or the right ventricle (i.e., tetralogy of Fallot and pulmonary stenosis); (3) complex cyanotic CHD (i.e., univentricular heart and transposition of the great arteries).
The N-terminal-pro-type B natriuretic peptide (NTproBNP) is 76 amino acids derived from cleavage of a prohormone of 108 amino acids synthesized and released by cardiomyocytes. NT-proBNP can be used as an adjunctive marker in the integrated screening, diagnosis, management, and follow-up of children with heart failure caused by various acquired and congenital heart diseases [6]. The natriuretic peptides, NT-proBNP and BNP, correlate with various indexes of disease severity in children with congenital heart defects. The measurement of the circulating cardiac biomarkers BNP and NT-proBNP is now recommended by international guidelines $[7,8]$.

Hypovitaminosis D is prevalent worldwide: around 37\% of studies evaluating the vitamin D status in various 
populations reported mean values below $20 \mathrm{ng} / \mathrm{mL}$ [9]. Pediatric patients with congenital heart defects might be a population at high risk of hypovitaminosis D due to their chronic disease and to the reduced exposure to sunlight. Vitamin D is key component of the calcium metabolism. Calcium and the calciotropic hormones, vitamin D and parathormone (PTH), exert direct and indirect effects on cardiomyocytes. Calcium dyshomeostasis associated with hypocalcemia, hypovitaminosis $\mathrm{D}$, and secondary hyperparathyroidism can lead to the development of dilated cardiomyopathy with lifethreatening consequences in both infants $[10,11]$ and adults [12]. Moreover, cardiomyocytes express both the vitamin D receptors and the PTH receptors (PTHR1), and studies in rodents have shown that vitamin $\mathrm{D}$ protects against cardiac hypertrophy and myocardial dysfunction [13-16]. In line with experimental data, vitamin $\mathrm{D}$ deficiency has been associated with a poor prognosis in adult patients with heart failure [17], and circulating PTH levels are related with an increased risk of cardiovascular events and mortality [18-20].

In the present study, we tested the hypothesis that vitamin $\mathrm{D}$ status might influence cardiac performance and therefore the circulating NT-proBNP levels in young patients with congenital heart defects. We investigated (1) the vitamin D status and (2) the correlations of calcium metabolism markers with serum NT-proBNP levels in a consistent series of young patients with various congenital heart defects.

\section{Patients and Methods}

2.1. Study Population. Two hundred thirty young patients (117 females, 113 males; 6.4 (4.0-9.1) years (median age, interquartile range)) with $\mathrm{CHD}$, referred to the Policlinico San Donato Pediatric Cardiosurgery between January 2007 and January 2009, were consecutively enrolled. All patients were studied at the admission to be evaluated for congenital heart defects and to undergo open or transcatheter surgical correction when haemodynamically significant CHD was diagnosed. In particular, 153 patients harboured defects determining increased volume overload (i.e., defects characterized by left-to-right shunt, such as ventricular septal defect, patent ductus arteriosus, truncus arteriosus, atrial septal defect, and atrioventricular septal defects); 62 patients had heart defects with pressure overload involving the left ventricle (i.e., aortic stenosis and aortic coarctation) or the right ventricle (i.e., tetralogy of Fallot and pulmonary stenosis); and 15 patients were affected with complex cyanotic CHD (i.e., univentricular heart and transposition of the great arteries).

Anamnestic and anthropometric parameters were recorded. Height was evaluated by height standard deviation score (HSDS) related to Italian growth curves for children aged 2-20 years [21]. HSDS for infants aged 0-2 years was calculated by using the Kabi-Pharmacia Growth Calculator, based on the British standards. Weight was evaluated by Weight-to-Height Index (WHP) expressed as the percentage of the median of the British standards using the Kabi-Pharmacia Growth Calculator. Clinical data are shown in Table 1. Exclusion criteria were considered overt cyanotic status, acute or chronic kidney failure, liver failure, infective and inflammatory diseases, acquired or metabolic cardiomyopathy, concurrent treatment with diuretics, amiodarone and steroids, ongoing calcium and/or vitamin D supplementation in the last 6 months, overt hypoparathyroidism, and overt or mild hypothyroidism.

Informed consent for personal data and blood collection was obtained by parents of all patients. The study was approved by the local ethical committee.

2.2. Measurements. Venous blood sampling was collected the day before the diagnostic procedure after an overnight fasting, and biochemical and hormonal markers were measured in all patients. Serum calcium, phosphate, magnesium, and creatinine were measured by routine assays. Serum calcium levels were corrected for the serum albumin concentrations according to the formula: serum total calcium $(\mathrm{mg} / \mathrm{dL})-0.8$ $\times$ [serum albumin $(\mathrm{g} / \mathrm{dL})-4.0]$. Serum albumin concentrations were within the normal range in all patients indicating the absence of malnutrition. Ionized calcium concentrations were assayed by Liquichek Blood Gas (IL Synthesis Series, Bio-Rad Laboratories, Segrate, MI, Italy). Serum 25OHD concentrations were measured by a chemiluminescent assay (LIAISON test, DiaSorin Inc., Stillwater, MN, USA) with mean intra- and interassay coefficients of variation (CV) of $4.5 \%$ and $7.5 \%$, respectively. Serum NT-proBNP and PTH were measured by Electrochemiluminescence on an Elecsys 2010 (Roche Diagnostics, Mannheim, Germany).

2.3. Statistical Analysis. Continuous parameters following a nonnormal distribution were presented as median and interquartile range (IQ). Normally distributed parameters were presented as mean \pm standard deviation; categorical data were given as percentages. Based on serum 25OHD concentrations, we formed four categories according to widely used cut-off values [22-24]: severe deficiency, less than $10.0 \mathrm{ng} / \mathrm{mL}$; moderate deficiency, $10.0-19.9 \mathrm{ng} / \mathrm{mL}$; insufficiency, 20.0$29.9 \mathrm{ng} / \mathrm{mL}$; and $25 \mathrm{OHD}$ optimal range, 30.0-100.0 ng/mL. For nanomoles per liter, multiply by 2.496. Serum 25OHD, PTH, and NT-pro-BNP concentrations were logarithmically transformed before being used in parametric procedures. Comparisons among CHD groups were performed by analysis of variance (ANOVA) with $P$ for linear trend for continuous parameters or ANOVA on ranks for nonparametric data. A $\chi^{2}$ test was performed for categorical variables. Simple correlation analyses (Pearson or Spearman correlations where appropriated) and multiple linear regression analyses including several independent variables were performed to examine whether 25OHD levels were associated with NTpro-BNP levels. A $P$ value $<0.05$ was considered statistically significant. Data were analysed using SPSS 22.0 statistical package (SPSS 22.0 Inc., Chicago, IL).

\section{Results}

3.1. Vitamin D Status in Young CHD Patients. Assessment of serum 25OHD levels in all CHD patients showed a high prevalence of vitamin D deficiency: serum 25OHD levels < $20 \mathrm{ng} / \mathrm{mL}$ were detected in $55.3 \%$ of young CHD patients and severe vitamin D deficiency $(25 \mathrm{OHD}<10 \mathrm{ng} / \mathrm{mL})$ occurred in $17.6 \%$ of patients. Adequate vitamin D levels, defined as 
TABLE 1: Clinical, biochemical, and hormonal features according to the vitamin D status in young CHD patients.

\begin{tabular}{|c|c|c|c|c|c|}
\hline \multirow{2}{*}{ Markers } & \multicolumn{4}{|c|}{ Serum 25OHD levels } & \multirow{2}{*}{$P$} \\
\hline & $<10.0 \mathrm{ng} / \mathrm{mL}$ & $10.0-19.9 \mathrm{ng} / \mathrm{mL}$ & $20.0-30.0 \mathrm{ng} / \mathrm{mL}$ & $>30.0 \mathrm{ng} / \mathrm{mL}$ & \\
\hline$N$ & 33 & 88 & 48 & 61 & \\
\hline Age (years) & $\begin{array}{c}8.3 \\
(5.6-11.2)\end{array}$ & $\begin{array}{c}5.8 \\
(3.8-9.0)^{*}\end{array}$ & $\begin{array}{c}7.1 \\
(4.6-9.4)\end{array}$ & $\begin{array}{c}5.7 \\
(2.8-8.7)^{*}\end{array}$ & 0.02 \\
\hline Male/female & $12 / 21$ & $43 / 45$ & $23 / 25$ & $35 / 26$ & ns \\
\hline HSDS & $\begin{array}{c}0.02 \\
(-0.54-0.65)\end{array}$ & $\begin{array}{c}-0.25 \\
(-1.09-0.77)\end{array}$ & $\begin{array}{c}-0.06 \\
(-1.4-0.31)\end{array}$ & $\begin{array}{c}-0.83 \\
(-1.6-0.11)^{*}\end{array}$ & 0.002 \\
\hline$W / H(\%)$ & $\begin{array}{c}101.5 \\
(91.5-112.5)\end{array}$ & $\begin{array}{c}97.0 \\
(93.0-107.0)\end{array}$ & $\begin{array}{c}102.0 \\
(94.0-114.5)\end{array}$ & $\begin{array}{c}95.0 \\
(88.0-104.5)^{\S}\end{array}$ & 0.03 \\
\hline $\begin{array}{l}\text { Creatinine } \\
(\mathrm{mg} / \mathrm{dL})\end{array}$ & $\begin{array}{c}0.46 \\
(0.37-0.57)\end{array}$ & $\begin{array}{c}0.41 \\
(0.36-0.51)^{*}\end{array}$ & $\begin{array}{c}0.45 \\
(0.38-0.51)\end{array}$ & $\begin{array}{c}0.40 \\
(0.32-0.45)^{*}\end{array}$ & 0.01 \\
\hline $\begin{array}{l}\text { Alb/calcium } \\
(\mathrm{mg} / \mathrm{dL})\end{array}$ & $\begin{array}{c}9.07 \\
(8.80-9.40)\end{array}$ & $\begin{array}{c}8.97 \\
(8.79-9.25)\end{array}$ & $\begin{array}{c}9.04 \\
(8.72-9.31)\end{array}$ & $\begin{array}{c}9.02 \\
(8.80-9.36)\end{array}$ & ns \\
\hline Ionized $\mathrm{Ca}(\mathrm{mmol} / \mathrm{L})$ & $\begin{array}{c}1.19 \\
(1.07-1.25)\end{array}$ & $\begin{array}{c}1.19 \\
(1.13-1.26)\end{array}$ & $\begin{array}{c}1.22 \\
(1.08-1.30)\end{array}$ & $\begin{array}{c}1.21 \\
(1.13-1.30)\end{array}$ & ns \\
\hline $\begin{array}{l}\text { Magnesium } \\
(\mathrm{mg} / \mathrm{dL})\end{array}$ & $\begin{array}{c}2.08 \\
(1.98-2.14)\end{array}$ & $\begin{array}{c}2.07 \\
(1.95-2.19)\end{array}$ & $\begin{array}{c}2.15 \\
(1.98-2.23)\end{array}$ & $\begin{array}{c}2.05 \\
(1.97-2.15)\end{array}$ & ns \\
\hline $\begin{array}{l}\text { Phosphate } \\
\text { (mg/dL) }\end{array}$ & $\begin{array}{c}4.86 \\
(4.37-5.38)\end{array}$ & $\begin{array}{c}5.18 \\
(4.75-5.67)\end{array}$ & $\begin{array}{c}5.28 \\
(4.77-5.65)\end{array}$ & $\begin{array}{c}5.11 \\
(4.69-5.67)\end{array}$ & ns \\
\hline $\begin{array}{l}\text { PTH } \\
(\mathrm{pg} / \mathrm{mL})\end{array}$ & $\begin{array}{c}34.0 \\
(21.5-52.5)\end{array}$ & $\begin{array}{c}31.0 \\
(24.2-48.7)\end{array}$ & $\begin{array}{c}31.5 \\
(23.2-43.5)\end{array}$ & $\begin{array}{c}27.0 \\
(17.5-38.0)^{*}\end{array}$ & 0.003 \\
\hline $\begin{array}{l}\text { NT-proBNP } \\
\text { (ng/mL) }\end{array}$ & $\begin{array}{c}104.6 \\
(63.2-179.7)\end{array}$ & $\begin{array}{c}89.1 \\
(43.7-149.2)\end{array}$ & $\begin{array}{c}129.7 \\
(57.5-283.3)\end{array}$ & $\begin{array}{c}128.3 \\
(62.9-193.6)\end{array}$ & ns \\
\hline
\end{tabular}

${ }^{*} P<0.05$ versus $25 \mathrm{OHD}<10 \mathrm{ng} / \mathrm{dL} ;{ }^{5} P<0.05$ versus $25 \mathrm{OHD} 20-30 \mathrm{ng} / \mathrm{dL} ; \mathrm{ns}$, not significant; Alb/calcium, albumin-corrected calcium; $W / H$, weight/height; HSDS, height standard deviation score; ionized Ca, ionized calcium.

serum $25 \mathrm{OHD}$ levels $>30 \mathrm{ng} / \mathrm{mL}$, were detected in about oneforth of the CHD patients. Vitamin D status did not differ between males and females nor among CHD groups. Young CHD patients with $25 \mathrm{OHD}<10 \mathrm{ng} / \mathrm{mL}$ did not complain for symptoms of rickets (bowed legs, thickened wrists and ankle, and breastbone projection).

Serum 25OHD levels negatively correlated with age $(r=$ $-0.169, P=0.013)$ (Figure 1(a)) and with height SDS $(r=$ $-0.269, P=0.001$ ) (Figure 1(b)), also after adjustment for age $(\beta=-0.200, P=0.002)$. Accordingly, CHD patients with severe vitamin D deficiency $(<10 \mathrm{ng} / \mathrm{mL})$ were older, heavier, and with higher median PTH levels than patients with an optimal vitamin D status ( $>30 \mathrm{ng} / \mathrm{mL}$ ) (Table 1), while serum 25OHD levels did not differ among the three CHD groups identified according the underlying congenital heart defect (Table 2).

3.2. Parathyroid Function in Young CHD Patients. Overt hypocalcemia and hypomagnesemia were considered exclusion criteria. Hypercalcemia, defined as elevated levels of serum albumin-corrected calcium and ionized calcium, was not detected in any patients. Hyperparathyroidism, defined as serum PTH levels in the higher quartile $(>44 \mathrm{pg} / \mathrm{mL})$, was diagnosed in 56 out of $230 \mathrm{CHD}$ patients (24.0\%). Serum PTH levels positively correlated with 25OHD levels $(r=$ $-0.216, P=0.001$; Figure $1(\mathrm{c}))$ also after adjustment for age
( $\beta=-0.200, P=0.002)$. In the present series, renal function was conserved in all CHD patients as confirmed by serum creatinine levels in the normal range.

3.3. Effect of Vitamin D Status and PTH Secretion Alterations on Serum NT-proBNP Levels. Serum NT-proBNP levels ranged from 5.1 to $5529.0 \mathrm{ng} / \mathrm{mL}$ in the present series of young CHD patients. Serum NT-proBNP levels did not show any significant correlation with age and did not differ among the different CHD groups (Table 2). Moreover, significant correlations between serum NT-pro-BNP levels and 25OHD (Figure 2(a)) as well as PTH and albumin-corrected calcium failed to be detected (Figure 2(b)).

\section{Discussion}

Circulating NT-proBNP is a cardiac biomarker for diagnosis, prognosis, and therapeutic monitoring. Data available so far in pediatric patients support the NT-proBNP measurement in specific cases [6]. Serum 25OHD and/or PTH levels have been shown to be independently associated with all cause and cardiovascular mortality in adult patients with heart failure [25-28]. Moreover, previous studies reported a negative correlation between serum 25OHD levels and NT-proBNP levels in adult patients with coronary artery diseases and heart failure $[27,29,30]$. Indeed, findings are 
TABLE 2: Clinical, biochemical, and hormonal features according the CHD type in young CHD patients.

\begin{tabular}{|c|c|c|c|c|}
\hline Markers & CHD1 & CHD2 & CHD3 & $P$ \\
\hline$n$ & 153 & 62 & 15 & \\
\hline Age (years) & $\begin{array}{c}6.4 \\
(4.3-9.2)\end{array}$ & $\begin{array}{c}7.5 \\
(3.8-10.3)\end{array}$ & $\begin{array}{c}5.4 \\
(2.6-6.7)\end{array}$ & ns \\
\hline Male/female & $65 / 88$ & $35 / 27$ & $11 / 4$ & ns \\
\hline HSDS & $\begin{array}{c}-0.13 \\
(-1.07-0.59)\end{array}$ & $\begin{array}{c}-0.54 \\
(-1.42-0.44)\end{array}$ & $\begin{array}{c}-0.92 \\
(-2.29-0.42)\end{array}$ & ns \\
\hline$W / H(\%)$ & $\begin{array}{c}98.0 \\
(92.0-107.0)\end{array}$ & $\begin{array}{c}98.5 \\
(93.0-110.3)\end{array}$ & $\begin{array}{c}93.0 \\
(84.0-107.0)\end{array}$ & ns \\
\hline $\begin{array}{l}\text { Creatinine } \\
(\mathrm{mg} / \mathrm{dL})\end{array}$ & $\begin{array}{c}0.42 \\
(0.36-0.50)\end{array}$ & $\begin{array}{c}0.44 \\
(0.36-0.55)\end{array}$ & $\begin{array}{c}0.41 \\
(0.35-0.45)\end{array}$ & ns \\
\hline $\begin{array}{l}\text { Alb/calcium } \\
\text { (mg/dL) }\end{array}$ & $\begin{array}{c}9.02 \\
(8.80-9.30)\end{array}$ & $\begin{array}{c}9.06 \\
(8.80-9.33)\end{array}$ & $\begin{array}{c}8.81 \\
(8.72-9.60)\end{array}$ & ns \\
\hline $\begin{array}{l}25 \mathrm{OHD} \\
(\mathrm{ng} / \mathrm{mL})\end{array}$ & $\begin{array}{c}19.0 \\
(12.8-30.0)\end{array}$ & $\begin{array}{c}21.3 \\
(12.5-33.4)\end{array}$ & $\begin{array}{c}17.9 \\
(11.9-30.7)\end{array}$ & ns \\
\hline $\begin{array}{l}\text { PTH } \\
(\mathrm{pg} / \mathrm{mL})\end{array}$ & $\begin{array}{c}31.0 \\
(22.0-44.5)\end{array}$ & $\begin{array}{c}28.5 \\
(20.5-41.0)\end{array}$ & $\begin{array}{c}35.0 \\
(26.0-59.0)\end{array}$ & ns \\
\hline $\begin{array}{l}\text { NT-proBNP } \\
(\mathrm{ng} / \mathrm{mL})\end{array}$ & $\begin{array}{c}104.6 \\
(60.1-182.5)\end{array}$ & $\begin{array}{c}109.8 \\
(54.7-200.9)\end{array}$ & $\begin{array}{c}70.0 \\
(41.0-97.9)\end{array}$ & $\mathrm{ns}$ \\
\hline
\end{tabular}

ns, not significant; Alb/calcium, albumin-corrected calcium; $W / H$, weight/height; HSDS, height standard deviation score; ionized Ca, ionized calcium.

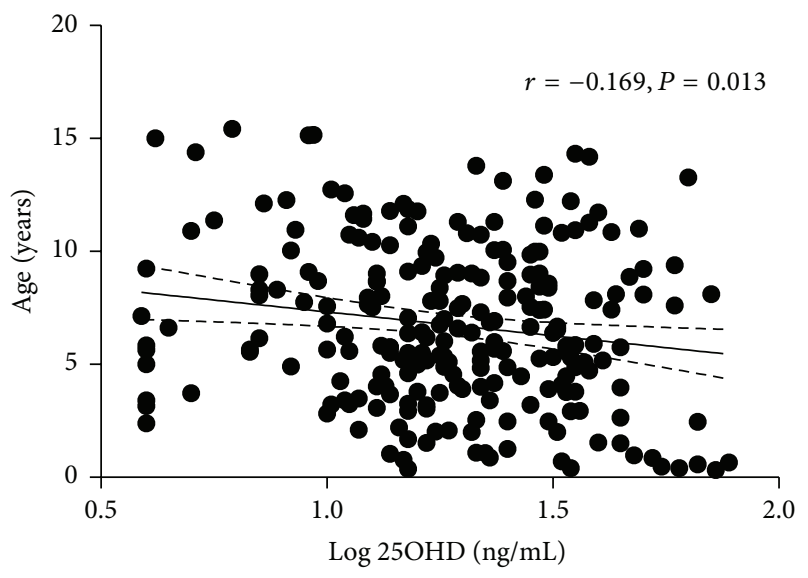

(a)

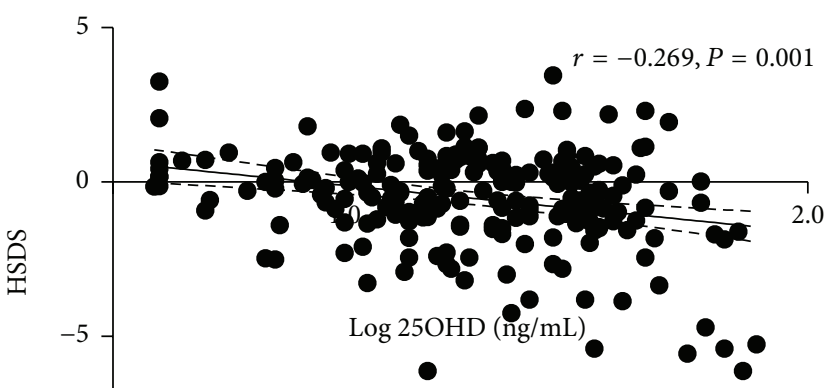

(b)

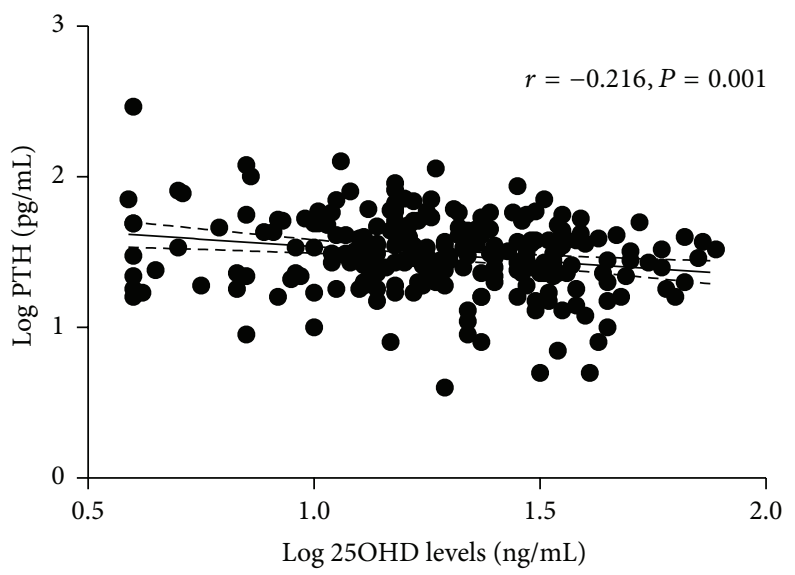

(c)

FIGURE 1: Correlations of serum 25OHD levels with clinical and hormonal markers in young CHD patients. (a) Log 25OHD levels were negatively correlated with age. (b) Log 25OHD levels negatively correlated with height SDS. (c) Log 25OHD levels negatively correlated with Log PTH levels. Best-fit line (continuous lines) and 95\% intervals of confidence (dashed lines) were shown. 


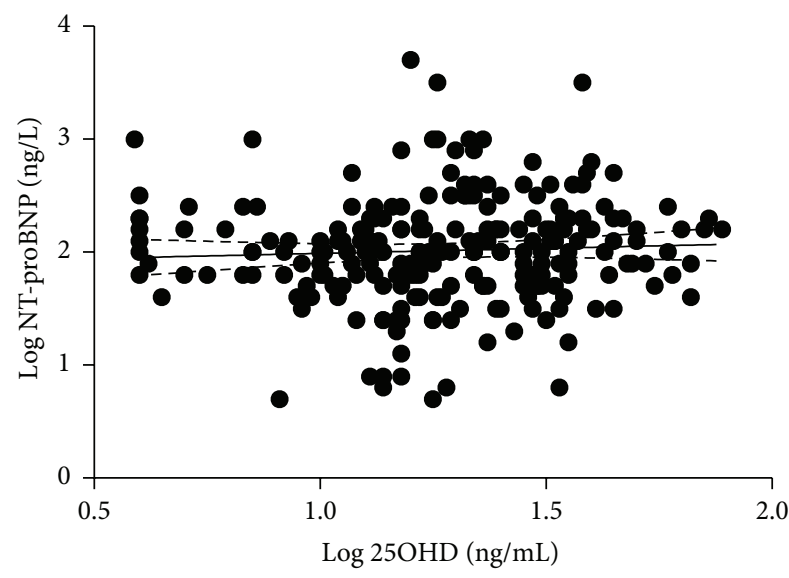

(a)

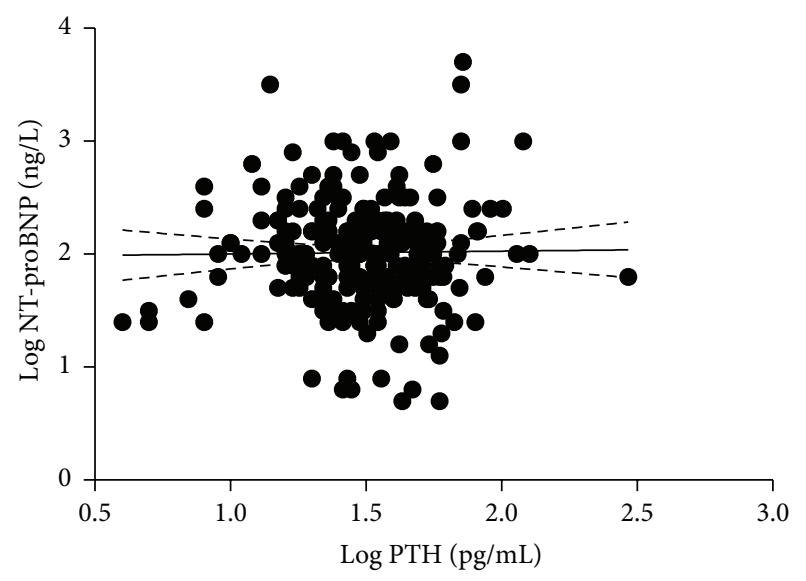

(b)

FIGURE 2: Lack of correlations of serum NT-proBNP levels and 25OHD and PTH levels in young CHD patients. (a) Log 25OHD levels were not correlated with Log NT-proBNP levels. (b) Log PTH levels were not correlated with Log NT-proBNP levels.

controversial as an investigation in the setting of adult postacute myocardial infarction failed in detecting an association between nutritional vitamin D status and NT-proBNP levels [31]. Moreover, a recent interventional study reported any significant effect of oral vitamin D supplementation on circulating NT-proBNP levels in adult peritoneal dialysis patients [32].

In the present series of young CHD patients, we failed in detecting such a relationship between 25OHD and NTproBNP levels as well as between PTH and NT-proBNP levels, though in the present young CHD cohort vitamin D deficiency and mild hyperparathyroidism frequently occurred.

Data about vitamin D status in young patients with CHD are scanty: Avitabile et al. [33] reported vitamin D deficiency, defined as serum $25 \mathrm{OHD}$ levels lower than $20 \mathrm{ng} / \mathrm{mL}$, in $25 \%$ of a small series of children and young adults $(n=50)$ with Fontan physiology, while McNally et al. [34] reported hypovitaminosis D in about $40 \%$ of 58 young CHD patients.

This is the first study investigating the preoperatively vitamin $\mathrm{D}$ status in a consistent series of young patients with various congenital heart defects. In the present series, hypovitaminosis D occurred in half of the patients. Children and adolescents have been reported to be potentially at high risk for vitamin $\mathrm{D}$ deficiency $[35,36]$. In Europe, where very few foods are fortified with vitamin $\mathrm{D}$, children would appear to be at especially high risk [34]. Indeed, the prevalence of hypovitaminosis $\mathrm{D}$ in the present series of CHD young patients was similar to that found in a cohort of Italian healthy children and adolescents [37], suggesting that most of the CHD conditions do not represent a risk factor for the development of hypovitaminosis $\mathrm{D}$ in children and adolescents. This point is further supported by the lack of significant differences in median 25OHD levels among the three pathophysiological CHD groups. Moreover, serum $25 \mathrm{OHD}$ levels were inversely related to CHD patients' age and height, suggesting, in line with a previous report [38], that older children and adolescents as well as subjects with overweight experience more frequently hypovitaminosis D.
Serum 1,25-dihydroxyvitamin D levels have been suggested to strongly and independently predict cardiovascular mortality in adult patients with chronic heart failure [39]. Therefore, 1,25-dihydroxyvitamin D levels might be more sensitive in detecting the correlation with NTproBNP levels in young CHD patients; unfortunately, 1,25dihydroxyvitamin $\mathrm{D}$ determinations were not available in the present series of CHD patients.

The serum PTH threshold of $44 \mathrm{pg} / \mathrm{mL}$, corresponding to the upper quartile of the PTH distribution in the young CHD patients, has been chosen to detect mild parathyroid function activation induced by vitamin $\mathrm{D}$ deficiency in young subjects with normal renal function [40, 41]. Indeed, PTH levels in healthy children and adolescents have been found to cover a narrower range than the adult values [42]. Considering this PTH threshold, about one-third of hypovitaminosis D young CHD patients showed hyperparathyroidism. Sustained rises in plasma PTH lead to intracellular $\mathrm{Ca}^{2+}$ overloading in diverse cells, including cardiomyocytes [43]. In turn, elevated energy ATP stores become depleted and ATPase-dependent $\mathrm{Ca}^{2+}$ efflux reduced, together with an induction of oxidative stress that can threaten cardiomyocyte survival. Though the experimental and clinical data suggest an association between NT-proBNP and PTH levels and support their role as predictors of clinical outcomes in adult with cardiovascular diseases, any significant association could be detected between NT-proBNP and PTH levels in young CHD patients.

In conclusion, vitamin $\mathrm{D}$ deficiency occurred in half of the young CHD patients and mild hyperparathyroidism could be detected in quarter of the patients. The circulating biomarker NT-proBNP was not related with both vitamin D status and PTH increases, suggesting that calcium metabolism aberrations might not affect circulating NTproBNP levels in young CHD patients.

\section{Conflict of Interests}

The authors have no conflict of interests to declare. 


\section{Acknowledgments}

The authors are in debt to Mrs. Simona Devecchi, chief nurse of Pediatric Cardiosurgery in IRCCS Policlinico San Donato, for her clinical support. This study was supported by IRCCS Policlinico San Donato Ricerca Corrente Fund.

\section{References}

[1] J. I. E. Hoffman and S. Kaplan, "The incidence of congenital heart disease," Journal of the American College of Cardiology, vol. 39, no. 12, pp. 1890-1900, 2002.

[2] J. I. E. Hoffman, S. Kaplan, and R. R. Liberthson, "Prevalence of congenital heart disease," American Heart Journal, vol. 147, no. 3, pp. 425-439, 2004.

[3] H. Dolk, M. Loane, and E. Garne, "The prevalence of congenital anomalies in Europe," Advances in Experimental Medicine and Biology, vol. 686, pp. 349-364, 2010.

[4] D. van der Linde, E. E. M. Konings, M. A. Slager et al., "Birth prevalence of congenital heart disease worldwide: a systematic review and meta-analysis," Journal of the American College of Cardiology, vol. 58, no. 21, pp. 2241-2247, 2011.

[5] B. Khoshnood, N. Lelong, L. Houyel et al., "Prevalence, timing of diagnosis and mortality of newborns with congenital heart defects: a population-based study," Heart, vol. 98, no. 22, pp. 1667-1673, 2012.

[6] M. Cantinotti, Y. Law, S. Vittorini et al., "The potential and limitations of plasma BNP measurement in the diagnosis, prognosis, and management of children with heart failure due to congenital cardiac disease: an update," Heart Failure Reviews, vol. 19, no. 6, pp. 727-742, 2014.

[7] K. Thygesen, J. Mair, C. Mueller et al., "Recommendations for the use of natriuretic peptides in acute cardiac care. A position statement from the Study Group on Biomarkers in Cardiology of the ESC Working Group on Acute Cardiac Care," European Heart Journal, vol. 33, no. 16, pp. 2001-2006, 2012.

[8] National Clinical Guideline Centre (UK), "Chronic heart failure: national clinical guideline for diagnosis and management in primary and secondary care," NICE Clinical Guidelines 108, 2010.

[9] J. Hilger, A. Friedel, R. Herr et al., "A systematic review of vitamin D status in populations worldwide," British Journal of Nutrition, vol. 111, no. 1, pp. 23-45, 2014.

[10] B. Bansal, M. Bansal, P. Bajpai, and H. K. Garewal, "Hypocalcemic cardiomyopathy-different mechanisms in adult and pediatric cases," Journal of Clinical Endocrinology and Metabolism, vol. 99, no. 8, pp. 2627-2632, 2014.

[11] W. Högler, "Complications of vitamin D deficiency from the foetus to the infant: one cause, one prevention, but who's responsibility?" Best Practice \& Research Clinical Endocrinology \& Metabolism, vol. 29, no. 3, pp. 385-398, 2015.

[12] A. S. Kazmi and B. M. Wall, "Reversible congestive heart failure related to profound hypocalcemia secondary to hypoparathyroidism," American Journal of the Medical Sciences, vol. 333, no. 4, pp. 226-229, 2007.

[13] G. Xiang, T. Seki, M. D. Schuster et al., "Catalytic degradation of vitamin D up-regulated protein 1 mRNA enhances cardiomyocyte survival and prevents left ventricular remodeling after myocardial ischemia," The Journal of Biological Chemistry, vol. 280, no. 47, pp. 39394-39402, 2005.
[14] N. Bodyak, J. C. Ayus, S. Achinger et al., "Activated vitamin $\mathrm{D}$ attenuates left ventricular abnormalities induced by dietary sodium in Dahl salt-sensitive animals," Proceedings of the National Academy of Sciences of the United States of America, vol. 104, no. 43, pp. 16810-16815, 2007.

[15] K. A. Nibbelink, D. X. Tishoff, S. D. Hershey, A. Rahman, and R. U. Simpson, "1,25(OH $)_{2}$-vitamin D3actions on cell proliferation, size, gene expression, and receptor localization, in the HL-1 cardiac myocyte," Journal of Steroid Biochemistry and molecular Biology, vol. 103, no. 3-5, pp. 533-537, 2007.

[16] D. X. Tishkoff, K. A. Nibbelink, K. H. Holmberg, L. Dandu, and R. U. Simpson, "Functional vitamin D receptor (VDR) in the t-tubules of cardiac myocytes: VDR knockout cardiomyocyte contractility," Endocrinology, vol. 149, no. 2, pp. 558-564, 2008.

[17] A. J. Meredith and B. M. McManus, "Vitamin D in heart failure," Journal of Cardiac Failure, vol. 19, no. 10, pp. 692-711, 2013.

[18] H. Altay, A. Zorlu, S. Binici et al., "Relation of serum parathyroid hormone level to severity of heart failure," The American Journal of Cardiology, vol. 109, no. 2, pp. 252-256, 2012.

[19] A. J. van Ballegooijen, I. Reinders, M. Visser, and I. A. Brouwer, "Parathyroid hormone and cardiovascular disease events: a systematic review and meta-analysis of prospective studies," American Heart Journal, vol. 165, no. 5, pp. 655.e5-664.e5, 2013.

[20] D. Gruson, S. A. Ahn, and M. F. Rousseau, "Multiple biomarker strategy based on parathyroid hormone and natriuretic peptides testing for improved prognosis of chronic heart failure," Peptides, vol. 64, pp. 24-28, 2015.

[21] E. Cacciari, S. Milani, A. Balsamo et al., "Italian cross-sectional growth charts for height, weight and BMI (2 to $20 \mathrm{yr}$ )," Journal of Endocrinological Investigation, vol. 29, no. 7, pp. 581-593, 2006.

[22] M. F. Holick, N. C. Binkley, H. A. Bischoff-Ferrari et al., "Evaluation, treatment, an prevention of vitamin D deficiency: an Endocrine Society clinical practice guideline," The Journal of Clinical Endocrinology \& Metabolism, vol. 96, pp. 1911-1930, 2011.

[23] A. C. Ross, J. E. Manson, S. A. Abrams et al., "The 2011 report on dietary reference intakes for calcium and vitamin $\mathrm{D}$ from the Institute of Medicine: what clinicians need to know," Journal of Clinical Endocrinology and Metabolism, vol. 96, no. 1, pp. 53-58, 2011.

[24] G. El-Hajj Fuleihan, R. Bouillon, B. Clarke et al., "Serum 25hydroxyvitamin D levels: variability, knowledge gaps, and the concept of a desirable range," Journal of Bone and Mineral Research, vol. 30, no. 7, pp. 1119-1133, 2015.

[25] E. Hagström, P. Hellman, T. E. Larsson et al., "Plasma parathyroid hormone and the risk of cardiovascular mortality in the community," Circulation, vol. 119, no. 21, pp. 2765-2771, 2009.

[26] L. L. Schierbeck, T. S. Jensen, U. Bang, G. Jensen, L. Køber, and J.-E. B. Jensen, "Parathyroid hormone and vitamin D-markers for cardiovascular and all cause mortality in heart failure," European Journal of Heart Failure, vol. 13, no. 6, pp. 626-632, 2011.

[27] L. C. Y. Liu, A. A. Voors, D. J. van Veldhuisen et al., "Vitamin D status and outcomes in heart failure patients," European Journal of Heart Failure, vol. 13, no. 6, pp. 619-625, 2011.

[28] S. G. Wannamethee, P. Welsh, O. Papacosta, L. Lennon, P. H. Whincup, and N. Sattar, "Elevated parathyroid hormone, but not vitamin $\mathrm{D}$ deficiency, is associated with increased risk of heart failure in older men with and without cardiovascular disease," Circulation: Heart Failure, vol. 7, no. 5, pp. 732-739, 2014. 
[29] S. Pilz, W. März, B. Wellnitz et al., "Association of vitamin $\mathrm{D}$ deficiency with heart failure and sudden cardiac death in a large cross-sectional study of patients referred for coronary angiography," Journal of Clinical Endocrinology and Metabolism, vol. 93, no. 10, pp. 3927-3935, 2008.

[30] D. Gruson, T. Lepoutre, S. A. Ahn, J. M. Ketelslegers, and M. F. Rousseau, "Comparison between intact and bioactive parathyroid hormone assays in patients with severe heart failure," Clinical Biochemistry, vol. 46, no. 4-5, pp. 391-394, 2013.

[31] J. B. Wetmore, R. Gadi, J. H. Lee et al., "Association of 25-hydroxyvitamin D deficiency with NT-pro BNP levels in patients with acute myocardial infarction: a cross-sectional analysis," BMC Research Notes, vol. 4, article 542, 2011.

[32] S. Seirafian, Y. Haghdarsaheli, M. Mortazavi, M. Hosseini, and F. Moeinzadeh, "The effect of oral vitamin D on serum level of Nterminal pro-B-type natriuretic peptide," Advanced Biomedical Research, vol. 3, no. 1, p. 261, 2014.

[33] C. M. Avitabile, M. B. Leonard, B. S. Zemel et al., "Lean mass deficits, vitamin D status and exercise capacity in children and young adults after Fontan palliation," Heart, vol. 100, pp. 17021707, 2014.

[34] J. D. McNally, K. Menon, P. Chakraborty et al., "Impact of anesthesia and surgery for congenital heart disease on the vitamin D status of infants and children: a prospective longitudinal study," Anesthesiology, vol. 119, no. 1, pp. 71-80, 2013.

[35] M. F. Holick, "Vitamin D deficiency," The New England Journal of Medicine, vol. 357, no. 3, pp. 266-281, 2007.

[36] A. J. Rovner and K. O. O’Brien, "Hypovitaminosis D among healthy children in the United States: a review of the current evidence," Archives of Pediatrics \& Adolescent Medicine, vol. 162, no. 6, pp. 513-519, 2008.

[37] S. Stagi, P. Pelosi, M. Strano et al., "Determinants of vitamin D levels in Italian children and adolescents: a longitudinal evaluation of cholecalciferol supplementation versus the improvement of factors influencing 25(OH)D status," International Journal of Endocrinology, vol. 2014, Article ID 583039, 13 pages, 2014.

[38] M. Smotkin-Tangorra, R. Purushothaman, A. Gupta, G. Nejati, H. Anhalt, and S. Ten, "Prevalence of vitamin D insufficiency in obese children and adolescents," Journal of Pediatric Endocrinology and Metabolism, vol. 20, no. 7, pp. 817-823, 2007.

[39] D. Gruson, B. Ferracin, S. A. Ahn et al., "1,25-dihydroxyvitamin D to $\mathrm{PTH}(1-84)$ ratios strongly predict cardiovascular death in heart failure," PLoS ONE, vol. 10, no. 8, Article ID e0135427, 2015.

[40] T. A. Outila, M. U. M. Kärkkäinen, and C. J. E. Lamberg-Allardt, "Vitamin D status affects serum parathyroid hormone concentrations during winter in female adolescents: associations with forearm bone mineral density," The American Journal of Clinical Nutrition, vol. 74, no. 2, pp. 206-210, 2001.

[41] L. Harkness and B. Cromer, "Low levels of 25-hydroxy vitamin $\mathrm{D}$ are associated with elevated parathyroid hormone in healthy adolescent females," Osteoporosis International, vol. 16, no. 1, pp. 109-113, 2005.

[42] S. Stagi, L. Cavalli, S. Ricci et al., "Parathyroid hormone levels in healthy children and adolescents," Hormone Research in Paediatrics, vol. 84, no. 2, pp. 124-129, 2015.

[43] M. R. Rutledge, V. Farah, A. A. Adeboye, M. R. Seawell, S. K. Bhattacharya, and K. T. Weber, "Parathyroid hormone, a crucial mediator of pathologic cardiac remodeling in Aldosteronism," Cardiovascular Drugs and Therapy, vol. 27, no. 2, pp. 161-170, 2013. 


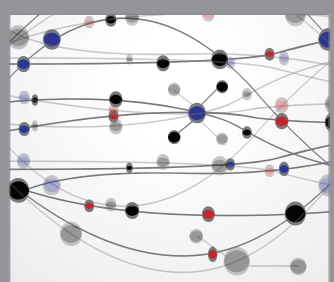

The Scientific World Journal
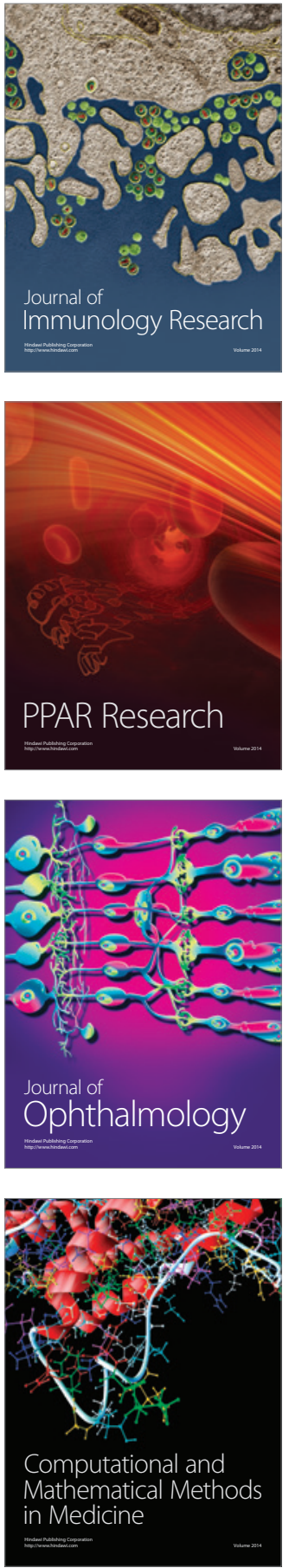

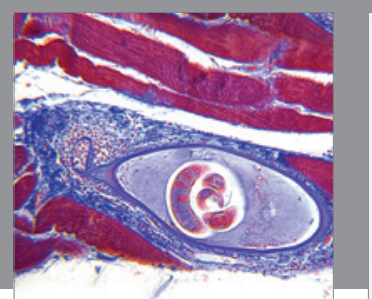

Gastroenterology Research and Practice

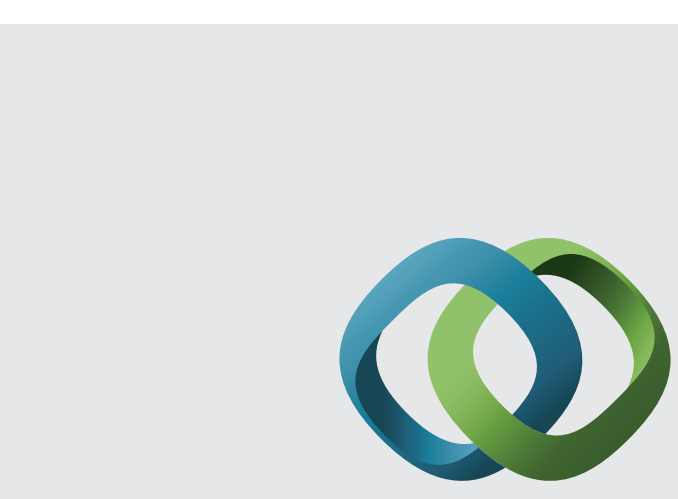

\section{Hindawi}

Submit your manuscripts at

http://www.hindawi.com
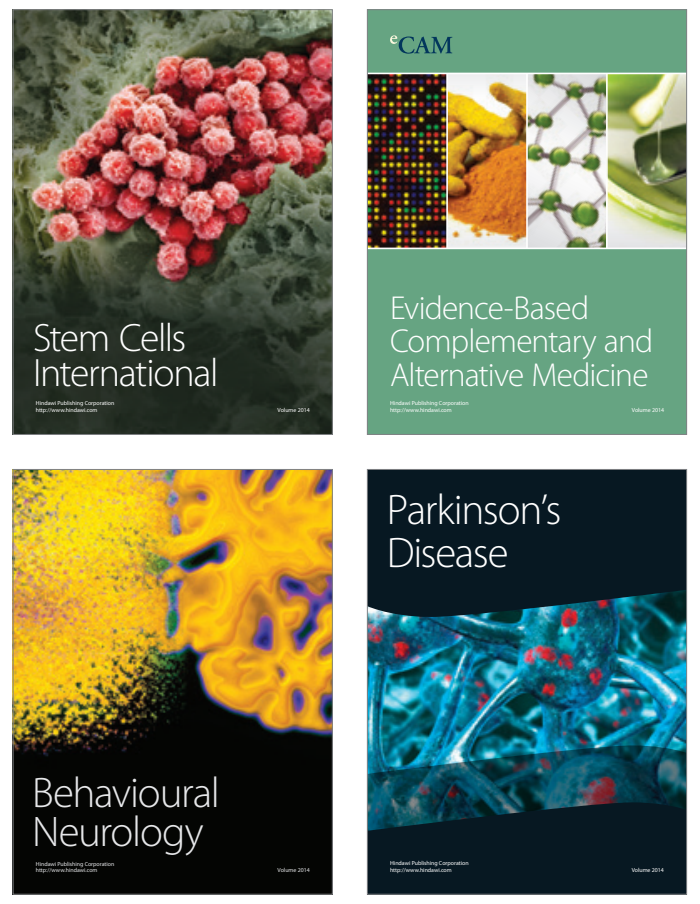
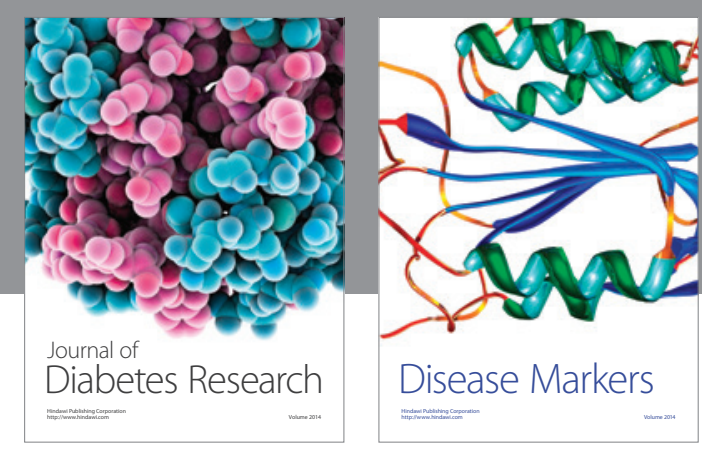

Disease Markers
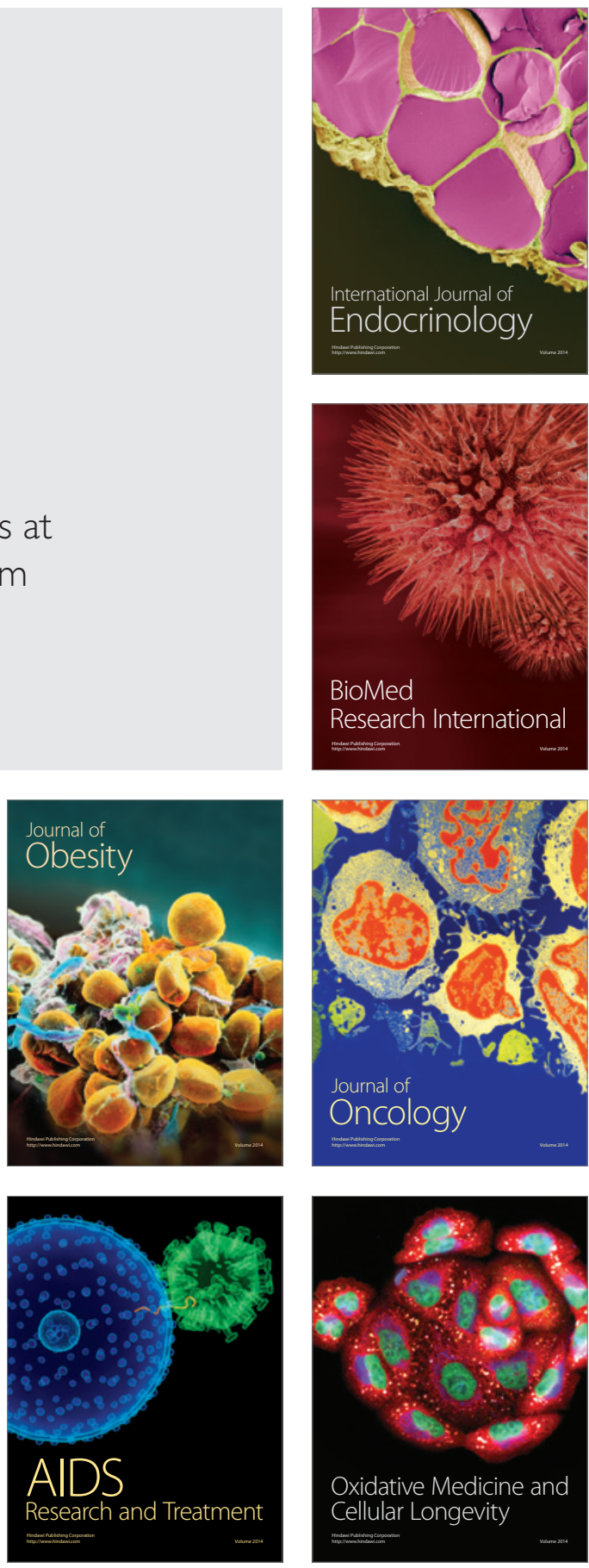